\title{
KEKUATAN HUKUM SURAT KETERANGAN TANAH ADAT (SKTA) YANG DIKELUARKAN OLEH DAMANG
}

\author{
Oleh : Sri Kayun*
}

\begin{abstract}
Abstrak
Dalam rangka pemberian jaminan kepastian hukum tersebut, kepada yang mendaftarkan tanahnya akan diberikan satu dokumen tanda bukti hak yang berfungsi sebagai alat pembuktian yang kuat. Dalam ketentuan Hukum Tanah Nasional dalam hal ini Peraturan Pemerintah Nomor 24 Tahun 1997 tentang Pendaftaran Tanah (selanjutnya disebut PP No.24/1997) hanya setifikat hak atas tanah yang diakui secara hukum sebagai bukti kepemilikan hak atas tanah yang menjamin kepastian hukum dan dilindungi oleh hukum.

Permasalahan dalam penelitian ini adalah 1). Bagaimana Kekuatan Hukum Surat Keterangan Tanah Adat (SKTA) yang dikeluarkan oleh Damang Kecamatan Rungan Hulu, Kabupaten Gunung Mas? 2). Apa Dasar Kewenangan Damang Dalam Membuat Surat Keterangan Tanah Adat (SKTA)? 3). Apakah Surat Keterangan Tanah Adat (SKTA) bisa ditingkatkan statusnya menjadi sertifikat?

Dari masalah tersebut menunjukan kekuatan hukum Surat Keterangan Tanah Adat (SKTA) yang dikeluarkan oleh Damang adalah memiliki kekuatan Hukum secara Hukum Adat berdasarkan Perda Kabupaten dan Pergub nomor 13 tahun 2009 tentang adat dan Hak-hak Adat diatas Tanah di Provinsi Kalimantan Tengah dan diperkuatkan dengan Peraturan Pemerintah Nomor 24 Tahun 1997 dan Undang-undang Nomor 5 Tahun 1960 tentang Peraturan Dasar Pokok-pokok Agraria ditugaskan kepada Pemerintah, merupakan sarana dalam memberikan jaminan kepastian hukum.
\end{abstract}

Kata Kunci : Kekuatan Hukum,SKTA, Damang.

\section{PENDAHULUAN}

Undang-Undang Pokok Agraria (UUPA) adalah sebutan lain dari Undang- undang Nomor 5 Tahun 1960 tentang Peraturan Dasar Pokokpokok Agraria. Undang-undang ini disahkan dan diundangkan pada tanggal 24 September 1960 di Jakarta. Tujuan dikeluarkannya UUPA adalah untuk mengakhiri dualisme hukum agraria di Indonesia pada saat itu.

Dalam kehidupan masyarakat telah diatur dengan berbagai macam aturan sebagaimana yang tertulis dalam UUD 1945 pasal 18B ayat 2 berbunyi sebagai berikut : 
Negara mengakui dan menghormati kesatuan-kesatuan masyarakat hukum adat beserta hak-hak tradisionalnya sepanjang masih hidup dan sesuai dengan perkembangan masyarakat dan prinsip Negara Kesatuan Republik Indonesia, yang diatur dalam undang-undang.

Berdasarkan pasal yang mengatur dalam bentuk Perundang-udangan tentang hak-hak atas tanah telah menjadi kekuatan hukum dalam kepemilikkan tanah, sehingga kedamangan membuat Surat keterangan Tanah Adat (SKTA) memiliki dasar hukum yang kuat sebagaiman tertuang dalam PERGUB nomor 13 Tahun 2009 Tentang Tanah Adat dan Hak-Hak Adat Di Atas Tanah Di Provinsi Kalimantan Tengah pasal 8 ayat 1,2 dan 3 berbunyi sebagai berikut :

Ayat 1 :

Surat Keterangan Tanah (SKT) Adat dan Hak-hak Adat di Atas Tanah yang menunjukan Hak Kepemilikan atau penguasaan Atas Tanah Adat Dan Hak-Hak Adat Di Atas Tanah dibuat:

a. Atas nama para ahli waris untuk Tanah Adat Milik Bersama;

b. Atas nama perorangan untuk Tanah Adat Milik Perorangan;

c. Atas nama para ahli waris atau atas nama perorangan untuk Hak- Hak Adat Di Atas Tanah.

Ayat 2 :

Surat Keterangan Tanah (SKT) Adat dan Hak-hak Adat di Atas Tanah sebagaimana dimaksud pada ayat (1) dapat dijadikan persyaratan utama untuk diproses sesuai ketentuan yang berlaku dalam rangka sertifikasi.

Ayat 3 :

Surat Keterangan Tanah (SKT) Adat dan Hak-hak Adat di Atas Tanah sebagaimana dimaksud dapat dijadikan syarat melakukan perjanjian pola kemitraan dengan Pihak lain di hadapan pejabat yang berwenang.

Berdasarkan pasal dan ayat tersebut maka sangat jelas bahwa masyarakat di Kecamatan Rungan Hulu akan mendapatkan kekuatan Hukum secara adat terhadap hak atas tanah ulayat apabila sudah mendapatkan Surat Keterangan Tanah Adat (SKTA) dari Kedamangan. Dengan permasalahan tersebut penulis merasa tertarik untuk mengangkat judul penelitian" Kekuatan Hukum Surat Keterangan Tanah Adat (SKTA) yang dikeluarkan oleh Damang. 


\section{PEMBAHASAN}

\section{Kekuatan Hukum Surat Keterangan Tanah Adat (SKTA) yang}

\section{dikeluarkan oleh Damang.}

Dalam rangka memberikan kepastian hukum kepada para pemegang hak atas tanah penegasan tentang sejauh mana kekuatan pembuktian sertifikat, yang dinyatakan sebagai alat pembuktian yang kuat. Untuk itu dikatakan bahwa selama dan sebelum dibuktikan sebaliknya atas data fisik dan data yuridis yang dicantumkan dalam sertifikat tersebut harus diterima sebagai data yang benar, baik dalam perbuatan hukum seharihari maupun dalam sengketa di Pengadilan sepanjang data tersebut sesuai dengan yang tercantum dalam surat ukur dan buku tanahnya.

Surat Keterangan Tanah Adat (SKTA) memiliki kekuatan Hukum secara Hukum Adat, dan diperkuatkan dengan Peraturan Pemerintah Nomor 24 Tahun 1997 dan Undang-undang Nomor 5 Tahun 1960 tentang Peraturan Dasar Pokok-pokok Agraria ditugaskan kepada Pemerintah, merupakan sarana dalam memberikan jaminan kepastian hukum.

Berdasarkan hasil wawancara dengan Mandar Gasan menjelaskan bahwa Surat Keterangan Tanah Adat (SKTA) yang dikeluarkan oleh Damang Kepala Adat memiliki kekuatan Hukum berdasarkan Peraturan Gubernur No. 13 Tahun 2009 Tentang Tentang Tanah Adat dan Hak-Hak Adat Di Atas Tanah Di Provinsi Kalimantan Tengah Pasal 14 ayat 1, 2 dan 3 berbunyi sebagai berikut:

(1) Pada saat mulai berlakunya Peraturan Gubernur ini, terhadap seluruh tanah adat dan hak-hak adat di atas tanah akan ditertibkan.

(2) Penertiban sebagaimana dimaksud pada ayat (1) akan diselesaikan paling lambat 6 (enam) tahun terhitung sejak diberlakukannya Peraturan Gubernur ini, meliputi kegiatan :

a. Inventarisasi Tanah Adat dan Hak-Hak Adat di atas

Tanah; 
b. Penerbitan Surat Keterangan Tanah Adat (SKTA) dan Surat Keterangan Hak-Hak Adat diatas Tanah;

c. Sertifikat dan atau pemutihan kepemilikan Tanah Adat.

(3). Perbuatan berupa tidak melakukan upaya inventarisasi berturutturut hingga 6 (enam) tahun terhitung sejak diundangkannya Peraturan Gubernur ini, dikenakan sanksi Adat berupa tidak diakuinya hak kepemilikan atau penguasaan dan pemanfaatan diatas Tanah Adat dimaksud serta sanksi tambahan sesuai Hukum Adat berlaku.

Berdasarkan ke 3 (tiga) poin tersebut sangat jelas bahwa kekuatan hukum Surat Keterangan Tanah Adat (SKTA) dipertegaskan dalam beberapa ketentuan kepemilikan Hak Atas.

Ketentuan mengenai pemberian hak milik atas tanah (baru) yang dikuasai negara dan atas hak pengolahan diatur dalam Peraturan Menteri Negara Agraria/Kepala BPN Nomor 9 Tahun 1999 tentang Tatacara Pemberian dan Pembatalan Hak atas Tanah Negara dan Hak Pengolahan (A. Patra M. Zen.2005:163).

Pasal 22 ditegaskan ada 3 (tiga) hal yang menjadi dasar hak atas Tanah:

a. Menurut Hukum Adat;

b. Karena Ketentuan Undang-Undang;

c. Karena Penetapan Pemerintah.

Terjadinya hak milik berdasarkan hukum adat yaitu yang diatur pada Pasal 16 UUPA bahwa hak-hak tanah berasal dari hukum adat atas se-izin masyarakat adat dan tanah yang telah diusahakan tersebut secara terus menerus bahkan turun temurun dapat diakui sebagai hak milik. Dalam hal ini Tanah Adat di wilayah Kecamatan Rungan Hulu, Kabupaten Gunung Mas.

Terjadinya hak milik berdasarkan ketentuan undang undang, yaitu berdasarkan konversi sebagaimana dimaksud pada ketentuan kedua (ketentuan- ketentuan konversi) UUPA, yakni: 
a. Konversi tanah-tanah eks hak egendom kepunyaan warga Negara Indonesia (yang dibuktikan pada tanggal 24 September 1960), dikonversi menjadi hak milik;

b. Konversi hak milik adat (hak-hak adat atas tanah) kepunyaan warga negara Indonesia dikonversi menjadi hak milik.

Terjadinya hak milik berdasarkan penetapan pemerintah dapat juga di dasarkan kepada:

a. Ketentuan landreform, yaitu seseorang yang memperoleh tanah dengan cara redistribusi obyek landreform oleh pemerintah yang akan ditingkatkan haknya menjadi hak milik (PP No. 224 Tahun 1961).

b. Pemberian hak milik berdasarkan yang berasal dari hak pengelolaan.

c. Pemberian hak milik berdasarkan konsolidasi tanah, transmigrasi, pencetakan sawah dan lain-lain sebagai tindak lanjut dari pelaksanaan landreform.

d. Peningkatan hak dari hak guna bangunan dan hak pakai menjadi hak milik.

e. Pemberian hak milik secara misal kepada beberapa orang berdasarkan pendaftaran tanah secara sistematik menurut PP No. 24 Tahun 1997 tentang Pendaftaran Tanah (Muhammad Yamin \& Chadidjah Dalimunthe.2009: 76).

Sedangkan Syarat-syarat Tanah Adat berdasarkan Pergub no. 13 Tahun 2009 Tentang Tanah Adat dan Hak-Hak Adat Di Atas Tanah Di Provinsi Kalimantan Tengah adalah sebagai berikut :

1). Foto copy KTP yang masih berlaku sejumlah 2 lembar.

2). Surat Pernyataan Penguasaan Fisik Bidang Tanah.

3). Surat Keterangan Kepala Desa/ Kelurahan.

4). PBB apabila memiliki. 
5). Surat kuasa apabila di pindah tangankan ke orang lain dalam hal Surat Keterangan Jual Beli yang di ketahui Kepala Desa/ RT setempat.

Setelah persyaratannya lengkap baru Fungsionaris Lembaga Kedamangan melakukan Inventarisasi, Pengukuran, Pematokan dan Pemetaan terhadap Tanah Adat Dan Hak-Hak Adat Di Atas Tanah, apabila sudah dilakukan Inventarisasi, maka selanjutnya dilakukan adalah:

1) Kerapatan Mantir Perdamaian Adat Kecamatan dan Desa/Kelurahan merupakan Lembaga Permusyawaratan Adat yang mengatur tentang kepemilikan, pengelolaan, penguasaan, pemanfaatan maupun pengalihan kepemilikan Tanah Adat Dan Hak-Hak Adat Di Atas Tanah.

2) Berita Acara Hasil Kerapatan Mantir Perdamaian Adat desa/ kelurahan dan Kecamatan, merupakan hasil kesepakatan musyawarah bersama seluruh anggota kerapatan yang wajib disahkan oleh Damang Kepala Adat.

3) Ketetapan kerapatan Mantir Perdamaian Adat sebagaimana dimaksud pada ayat (2) merupakan ketentuan hukum yang mengikat bagi setiap warga masyarakat adat Dayak.

4) Format Berita Acara Hasil Kerapatan Mantir Perdamaian Adat

Setelah dilakukan kerapatan Mantir Adat, Damang berhak mengeluarkan Surat Keterangan Tanah Adat (SKTA) sebagai Hak Milik Atas Tanah Adat tersebut.

\section{Dasar Kewenangan Damang Dalam Membuat Surat Keterangan Tanah}

\section{Adat (SKTA)}

Dalam pembuatan Surat Keterangan Tanah Adat (SKTA) dikeluarkan oleh Damang Kepala Adat berdasarkan PERDA Kabupaten Gunung Mas Nomor 33 Tahun 2011 tentang Kelembagaan Adat Dayak di Kabupaten Gunung Mas tertuang pada pasal 10 tentang Hak, Kewenangan dan Kewajiban ayat (1) poin d. berbunyi sebagai berikut: "Menetapkan Peraturan 
Damang, membuat Surat Keputusan, mengesahkan Surat Pernyataan, membuat Surat Keterangan Tanah Adat dan atau Hak-Hak Adat di atas Tanah." Menjadi dasar Hukum yang kuat sebagai acuan Damang Kepala Adat membuat Surat Keterangan Tanah Adat (SKTA).

Sedangkan menurut beberapa teori, berdasarkan UUPA no 5 Tahun 1960 dan Perda maupun Pergup nomor 13 Tahun 2009 tentang adat dan hakhak adat di atas tanah di Provinsi Kalimantan Tengah, Damang Kepala Adat berhak menggunakan teori Delegasi yaitu kewenangan yang dialihkan dari kewenangan atribusi dari suatu organ (institusi) pemerintah kepada organ lainnya. Sehingga delegator (orang yang telah memberi kewenangan) dapat menguji kewenangan tersebut atas namanya, sedangkan pada Mandat, tidak terdapat suatu pemindahan kewenangan tetapi pemberian Mandat (Mandator). Memberikan kewenangan kepada orang lain (Mandataris) untuk membuat keputusan atau mengambil suatu tindakan atas namanya.

\section{Surat Keterangan Tanah Adat (SKTA) bisa di tingkatkan statusnya menjadi sertifikat}

Hasil wawancara, dengan Oldrin menyatakan fakta yang terjadi di lapangan pelaksanaan kewenangan Damang Kepala Adat dalam pembuatan Surat Keterangan Tanah Adat ini sudah mulai berjalan pada awal tahun 2010. Namun dalam kenyataannya belum sesuai dengan yang diharapkan. Dalam hal ini masyarakat adat Dayak Ngaju, ada 2 orang yang mewakili pihak kerabat untuk mengajukan permohonan dibuatkan Surat Keterangan Tanah Adat kepada Damang Kepala Adat diwilayah tempat tinggal mereka. Lebih lagi di Kecamatan rungan yang sampai saat ini belum ada masyarakat adat Dayak Ngaju yang mengajukan permohonan Surat Keterangan Tanah Adat. Kedua, Kendala dalam pembuatan Surat Keterangan Tanah Adat sebagai dasar pensertifikatan tanah adat masyarakat Dayak Ngaju adalah kurang sosialisasi, pemahaman yang keliru, segi pendidikan yang rendah, kurangnya fasilitas kerja, serta biaya yang tidak pasti, hanya berdasarkan 
Peraturan Daerah Nomor 16 Tahun 2008 dan Pergub nomor 4 tahun 2012 tentang Perubahan atas Peraturan Gubernur Nomor 13 Tahun 2009 Tentang Tanah adat dan Hak-hak Adat diatas Tanah di Provinsi Kalimantan Tengah sebagai dasar untuk Pensertifikatan Tanah Adat Masyarakat Dayak Ngaju di Kecamatan Rungan.

Damang Kepala Adat membuat Surat Keterangan Tanah Adat (SKTA) wilayah Kecamatan Rungan Hulu berdasarkan aturan-aturan yang telah ditentukan oleh Lembaga Dewan Adat Dayak Kabupaten Gunung Mas dan Lembaga Dewan Adat Dayak Provinsi Kalimantan Tengah yaitu sebelum dikeluarkan Surat Keterangan Tanah Adat (SKTA) ada beberapa hal yang dipersiapkan sebagai berikut :

1).Hasil Inventarisasi Tanah Adat dan Hak-Hak Adat diatas Tanah.

2). Berita Acara Hasil Pemeriksa Tanah Adat

Pada umumnya, tanah girik (tanah adat) memiliki luas area yang melebihi luas tanah pada umumnya, hal tersebut didasari dari nenek moyang empu adat pada zaman dahulu menaklukkan atau menguasai sebuah area tanah tanpa patok-patok yang jelas. Kelengkapan yang harus dipersiapkan adalah Asli girik dan asli akta jual-beli, sebaiknya diusahakan jangan sampai dua berkas ini bermasalah, selain bermasalah dari segi kepemilikan serta akta yang diajukan bukan merupakan akta yang bersangkutan atas tanah girik tersebut.

Perubahan surat tanah menjadi sertifikat resmi akan memberikan kenyamanan serta keamanan bagi pemegang kuasa hak atas tanah tersebut, tanpa adanya sengketa antara tanah adat serta tanah yang dimiliki serta dikelola oleh pemerintah daerah. Cara merubah surat tanah (girik) menjadi sertifikat secara prosedural merupakan hal yang mudah dilakukan, walaupun waktu untuk mengurus dari tahap pertama sampai terakhir membutuhkan jangka waktu yang lama. Namun, dengan memiliki sertifikat asli dari BPN dengan ukuran patok-patok tanah yang jelas, maka dapat dipastikan bahwa Anda memiliki hak sah atas penguasaan tanah tersebut. 


\section{KESIMPULAN}

Berdasarkan hasil penelitian tentang "Kekuatan Hukum Surat Keterangan Tanah Adat (SKTA) yang dikeluarkan oleh Damang, maka dapat ditarik beberapa kesimpulan sebagai berikut :

1. Kekuatan Hukum Surat Keterangan Tanah Adat (SKTA) yang dikeluarkan oleh Damang Kecamatan Rungan Hulu, Kabupaten Gunung Mas adalah memiliki kekuatan Hukum secara Hukum Adat berdasarkan Perda Kabupaten dan Pergub nomor 4 tahun 2012 tentang Perubahan atas Peraturan Gubernur Nomor 13 Tahun 2009 Tentang Tanah adat dan Hak-hak Adat diatas Tanah di Provinsi Kalimantan Tengah dan diperkuatkan dengan Peraturan Pemerintah Nomor 24 Tahun 1997 dan Undang-undang Nomor 5 Tahun 1960 tentang Peraturan Dasar Pokok-pokok Agraria ditugaskan kepada Pemerintah, merupakan sarana dalam memberikan jaminan kepastian hukum.

2. Dasar Kewenangan Damang Dalam Membuat Surat Keterangan Tanah Adat (SKTA) adalah berdasarkan PERDA Kabupaten Gunung Mas Nomor 33 Tahun 2011 tentang Kelembagaan Adat Dayak di Kabupaten Gunung Mas tertuang pada pasal 10 tentang Hak, Kewenangan dan Kewajiban ayat (1) poin d. berbunyi sebagai berikut : "Menetapkan Peraturan Damang, membuat Surat Keputusan, mengesahkan Surat Pernyataan, membuat Surat Keterangan Tanah Adat dan atau Hak-Hak Adat di atas Tanah." Menjadi dasar Hukum yang kuat sebagai acuan Damang Kepala Adat membuat Surat Keterangan Tanah Adat (SKTA).

3. Surat Keterangan Tanah Adat (SKTA) bisa ditingkatkan statusnya menjadi sertifikat adalah pada dasarnya untuk meningkatkan surat tanah tersebut menjadi sertifikat kepemilikan yang sah bisa akan tetapi membutuhkan waktu lama sekitar 9 bulan. Bukan waktu yang ringkas, tapi dasar kelengkapan yang harus dipersiapkan Asli girik (surat Keterangan Tanah Adat) dan asli akta jual-beli, sebaiknya diusahakan jangan sampai dua berkas ini bermasalah, selain bermasalah dari segi 
kepemilikan serta akta yang diajukan bukan merupakan akta yang bersangkutan atas tanah girik tersebut.

\section{DAFTAR PUSTAKA}

Badan Pertanahan Nasional,2005. Jaminan UUPA Bagi Keberhasilan Pendayagunaan Tanah, Jakarta ; Biro Hukum dan Humas BPN.

Boedi Harsono. 2005, Hukum Agraria Indonesia, Sejarah Pembentukan Undang- Undang Pokok Agraria, Isi dan Pelaksanaannya, Jilid 1 Hukum Tanah Nasional, Jakarta: Djambatan, Edisi Revisi.

Irawan Soerodjo.2003, Kepastian Hukum Pendaftaran Tanah,Yogyakarta : Arloka.

Muhammad Yamin \& Chadidjah Dalimunthe, 2009, Modul Hukum Agraria, Medan: Program Studi Magister Kenotariatan Sekolah Pascasarjana Universitas Sumatera Utara.

Undang-Undang nomor 5 tahun 1960, tentang Peraturan Dasar PokokPokok Agraria.

Partanto A. dan Al Barry. 1994, Kamus Ilmiah Populer, Surabaya : Arloka.

Tim Penyusun, 2009. PERGUB Nomor 13 Tahun 2009 TentangTanah Adat dan Hak-Hak Adat diatas Tanah di Provinsi Kalimantan Tengah,Palangka Raya.

Supriadi, 2007. Hukum Agraria, Jakarta : Sinar Grafika. 